\title{
Students Exercise Patterns During the COVID-19 Pandemic
}

\author{
Kunjung Ashadi ${ }^{1, *}$ Imam Marsudi $^{1}$ Azizati Rochmania ${ }^{1}$ Ika Jayadi $^{1}$ Fifit Y. \\ Wulandari ${ }^{1}$ Gigih Siantoro ${ }^{1}$ \\ ${ }^{1}$ Sport Coaching Education, Faculty of Sport Science, Universitas Negeri Surabaya, Surabaya, Indonesia \\ *Corresponding author. Email: kunjungashadi@unesa.ac.id
}

\begin{abstract}
The COVID-19 pandemic risks causing a decrease in individual physical activity. The research objective was to determine the patterns of physical activity of students while at home during the COVID-19 pandemic. The research method used is a quantitative method with a descriptive approach and uses a Likert scale questionnaire that is distributed via Google Form to the subjects of the study, amounting to 445 students in the department of sports coaching education. The data analysis technique used is the average, standard deviation, percentage, minimum and maximum values. The results showed that as many as $83.2 \%$ of changes in exercise frequency, $80.9 \%$ of changes in exercise duration, and $82.3 \%$ of changes in exercise intensity. One of the causes of changes the exercise patterns is due to $58.7 \%$ of the all subjects work to increase income during the pandemic. It can be concluded that during the pandemic, the majority of students changes their exercise patterns.
\end{abstract}

\section{Keywords: COVID-19, Exercise, Physical Activity, Pandemic, Patterns, Students}

\section{INTRODUCTION}

COVID-19 is an infectious disease caused by a new type of coronavirus that was discovered in 2019 [1]. COVID-19 has similarities with Severe Acute Respiratory Syndrome (SARS) which occurred in 2002 and the Middle East respiratory syndrome (MERS) which occurred in 2012, where the disease was caused by the corona virus [2]. The three epidemics of the disease attack the human respiratory system acutely, causing death. In particular, COVID-19 has phylogenetic similarities to Severe Acute Respiratory Syndrome or SARS $^{[3]}$. COVID-19 is easily transmitted from the individual to other people through droplets or splashes of sneezing and saliva as well as direct contact with people with COVID-19[4]. To prevent wider transmission of COVID-19, the important steps are needed, one of which is covering the nose with the elbow when sneezing and wearing a mask and doing physical distancing. The physical distancing is an effort to break the chain of the spread of COVID-19, this has an impact on the pattern of limiting human activities in various sectors of life, especially in education systems.

The Sports Coaching Education Study Program, the Faculty of Sports of the State University of Surabaya has also carried out the order issued by the Government regarding the policy of studying from home as a form of physical distancing. Before the pandemic, all students carry out theoretical and practical lectures with face-toface methods but during the pandemic, all students carry out online lectures via video conferencing. All students also miss the moment where to carry out sports activities on campus, both through practical lectures and Student Activity Units. Sports activities are replaced by practicing online at home. This online-based learning activity has been implemented in the State University of Surabaya since March 2020 during the pandemic COVID-19 [5].

In the course process, the majority of students use video conferencing facilities to connect lecturers and students. This makes students hold a lot of gadgets for a long time to listen to the lecture process and work on assignments given by lecturers. Based on the results of questions and answers to 19 students of the Sports Coaching Education Study Program, it is shown that they conduct video conferences with course lecturers for 3-4 hours per day. Take the time to play on their cell phone while sitting or lying on the bed for 5 hours a day.

Furthermore, based on research data conducted by the Ministry of Education and Culture, it is known that the majority of students doing distance learning mostly use cell phones with a percentage of $68 \%$, the rest use laptops and tablets [6]. With the form of a cell phone that is compact and lightweight, students can do it with a cell phone anywhere, including while sleeping on the bed. The main difference between lectures that are conducted 
face-to-face and lectures from home lies in the absence of practical activities where all practical activities are eliminated and replaced through face-to-face video conferencing.

If this is not prevented wisely, then this has the risk of making students experience a lack of movement. Besides, the limited access to leave the house tends to make students stay at home for a long time. This has the risk of making students experience a sedentary lifestyle by tending to sit still for long periods and experiencing a lack of mobility, which harms themselves.

Even though it is known that the sedentary lifestyle harms the human body. Negative impact on physical and mental health [7], such as decreased muscle mass, cardiovascular fitness, weight gain [8], psychosocial problems [9] and even decreased academic [10]. WHO data shows that before the COVID-19 pandemic, the global trend shows that there is a lack of physical movement among adolescents around the world, with data in Indonesia of $86.4 \%$ of adolescents experiencing a lack of physical movement [11]. This might get worse in this COVID-19 condition.

Actually we must always stay productive and exercise during the COVID-19 pandemic. Physical activity can be done at home with a variety of physical activities with moderate intensity, for example walking in the house, strength training, flexibility, cardiovascular endurance, and a combination of these sports [12]. This is important to maintain immunity during this pandemic. High immunity is needed at this time so that students are not susceptible to COVID-19 and pass it on to other people. By having high immunity, it will be a positive step to prevent the spread of the COVID-19 chain.

In this regard, as a study program that cares about the resource assets owned, namely students, in particular, the students of Sports Coaching Education Study Program seeks to support the government's efforts to fight COVID-19, one of which is with policies related to physical activity and sports for students. The problem form this study does not have data about study activity patterns during this pandemic of students of sports coaching education study program. With the policy of studying from home, it is not known whether this also changes the pattern of their physical activity who previously tended to be active and did a lot of physical activity through lectures and replaced it with a balance of physical exercise independently in their respective homes and this is a big question.

Even though knowing about the pattern of student activity, this can be followed up as a program or policy that can be carried out by the students of the sports coaching education program during the COVID-19 pandemic to have students who are healthy and have sufficient physical activity. Therefore this research is very important to do as a basis for making policies for the students of sport coaching education programs regarding the prevention and handling of COVID-19 in students. On a limited scale by having students who are healthy and have good immunity, this is one real step in the effort to fight COVID-19.

\section{METHODS}

This research uses a quantitative descriptive approach with the subjects in this study were 445 students who came from 12 classes from a total of three batches of students, namely students class 2017, 2018 and 2019 who were studying at Sports Coaching Education - Faculty of Sports Science - the State University Of Surabaya. The sampling technique used was purposive sampling with the following considerations: 1) Students in semester 2 to 6. Students in semester 8 were not included in the sampling because the majority had graduated and entered the world of work. 2) Become a member of their respective class WhatsApp group. 3) Answer the questionnaire completely by the predetermined period.

To obtain data on physical activity patterns from the research subjects, this research used a questionnaire with a Likert scale. The questionnaire consisted of 20 questions containing the patterns of student sports activities before and during the COVID-19 pandemic. The questionnaire was made in the form of a google form that was sent to students via the WhatsApp group of each class. The data collection period was carried out in a period of one month from June to July 2020. The data collected were then grouped according to the same type of question to determine the comparison of patterns before and during the COVID-19 pandemic. The data obtained were analyzed using a percentage.

\section{RESULTS}

The gender profile of research subjects consisting of 445 students is shown in figure 1. 
Gender of research subject

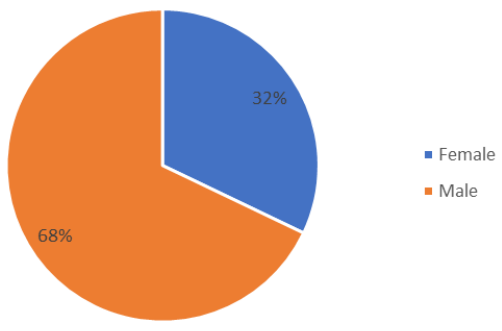

Figure 1 Gender of research subject

Based on Figure 1, it is known that the majority of the study subjects were male. Furthermore, the age division profile of the subjects is shown in Figure 2.

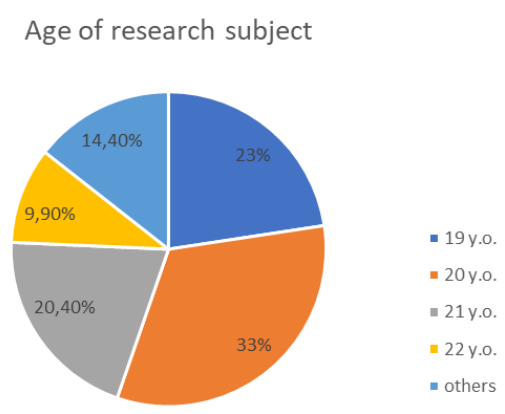

Figure 2 Age profile of research subjects

Base on figure 2 known that the majority of research subjects were in the age range of 20 years $(32.7 \%), 19$ years $(22.6 \%), 21$ years $(20.4 \%)$ and 22 years $9.9 \%$ ) while the rest were under the age of 19 or over 22 years. Furthermore, the opinions of research subjects about the importance of maintaining physical conditions during the COVID-19 pandemic are shown in figure 3.

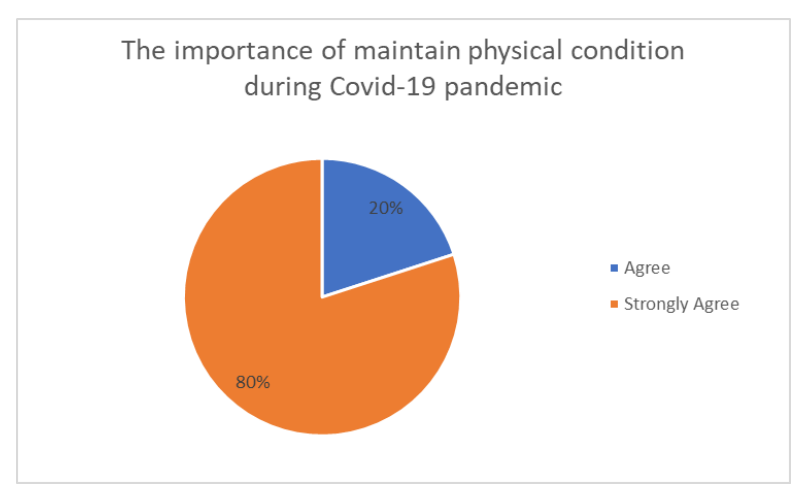

Figure 3 The importance of maintaining physical condition

Based on the results of the research subjects' answers, it is known that maintaining physical condition during the COVID-19 pandemic is important. This is indicated by $80 \%$ strongly agree and another $20 \%$ agree that it is important to maintain endurance during the COVID-19 pandemic. The research subjects argued that sports activity was the right way to maintain physical condition during the COVID-19 pandemic which is shown in table 1.

Table 1. The sports activity is an important way to maintain immune system

\begin{tabular}{|c|c|}
\hline \multicolumn{2}{|c|}{ The sports activity is an important way } \\
\hline Agree & Strongly Agree \\
\hline $30 \%$ & $70 \%$ \\
\hline
\end{tabular}

The subjects argue that sports activity is an important way to do during the COVID-19 pandemic. This is indicated by $70 \%$ strongly agree and the remaining $30 \%$ agree that sports activities are one of the right ways to maintain immunity during the COVID-19 pandemic. The COVID-19 pandemic caused changes in exercise habits in study subjects. This is shown in table 2.

Table 2. The percentage of exercise habits

\begin{tabular}{|c|c|c|}
\hline $\begin{array}{c}\text { Exercise } \\
\text { habits }\end{array}$ & Before pandemic & During Pandemic \\
\hline Always & $31,2 \%$ & $22,6 \%$ \\
\hline Often & $47,8 \%$ & $39,9 \%$ \\
\hline Sometimes & $17,7 \%$ & $27,8 \%$ \\
\hline Seldom & $2,9 \%$ & $8,5 \%$ \\
\hline Never & $0,4 \%$ & $1,1 \%$ \\
\hline
\end{tabular}

Based on the data, this pandemic has caused changes in the pattern of sports activity in college students of sports coaching education. Changes in the frequency of training also occurred during the COVID-19 pandemic. The change in training frequency patterns is shown in table 3 .

Table 3. The percentage of frequency of exercise

\begin{tabular}{|c|c|c|}
\hline $\begin{array}{c}\text { Frequency of } \\
\text { exercise }\end{array}$ & $\begin{array}{c}\text { Before } \\
\text { pandemic }\end{array}$ & $\begin{array}{c}\text { During } \\
\text { Pandemic }\end{array}$ \\
\hline Never & $0 \%$ & $2,2 \%$ \\
\hline $1-3$ times & $28 \%$ & $45,7 \%$ \\
\hline 3-5 times & $44,2 \%$ & $35 \%$ \\
\hline $\begin{array}{c}\text { More than 5 } \\
\text { times }\end{array}$ & $27,6 \%$ & $17 \%$ \\
\hline
\end{tabular}


The table 3 shown that the subjects changes their frequency of exercise each week. The changes shown were a decrease in the frequency of exercise. As much as $83,2 \%$ of students experienced a decrease in the frequency of training each week. Changes in the duration of training also occurred during the COVID-19 pandemic. The change in training frequency patterns is shown in table 4.

Tabel 4. The percentage of duration of exercise

\begin{tabular}{|c|c|c|}
\hline $\begin{array}{c}\text { Duration of } \\
\text { exercise }\end{array}$ & $\begin{array}{c}\text { Before } \\
\text { pandemic }\end{array}$ & $\begin{array}{c}\text { During } \\
\text { Pandemic }\end{array}$ \\
\hline $0-15$ minutes & $3,6 \%$ & $4,9 \%$ \\
\hline $15-30$ minutes & $10,3 \%$ & $22,6 \%$ \\
\hline $30-45$ minutes & $17 \%$ & $26,5 \%$ \\
\hline $45-60$ minutes & $22,4 \%$ & $25,1 \%$ \\
\hline $\begin{array}{c}\text { More than } 60 \\
\text { minutes }\end{array}$ & $46,6 \%$ & $20,9 \%$ \\
\hline
\end{tabular}

Based on the data, indicated that there was a decrease in the duration of the exercise. The subjects also applies to changes in the pattern of exercise duration time where $80.9 \%$ of the subjects experienced changes in exercise time. Furthermore, changes in exercise intensity before and during the COVID19 pandemic are shown in Table 5 .

Table 5. The percentage of intensity of exercise

\begin{tabular}{|c|c|c|}
\hline \multicolumn{3}{|c|}{ The intensity of exercise } \\
\hline & Before pandemic & During Pandemic \\
\hline Very low & $2,9 \%$ & $12,1 \%$ \\
\hline Low & $8,5 \%$ & $21,7 \%$ \\
\hline Moderate & $48,4 \%$ & $53,8 \%$ \\
\hline High & $34,1 \%$ & $11 \%$ \\
\hline Very high & $6,1 \%$ & $1,3 \%$ \\
\hline
\end{tabular}

From the table 5 shown this pandemic condition also affects the intensity of student training. The results shown that the $82.3 \%$ subjects changed their exercise intensity patterns. These changes are in the form of a decrease in the intensity of exercise in students. The changes in the types of sports activities carried out by the research subjects also changed. This is shown in table 6 .

Table 6. The sport type of exercise

\begin{tabular}{|c|c|c|}
\hline $\begin{array}{c}\text { The sport type of } \\
\text { exercise }\end{array}$ & $\begin{array}{c}\text { Before } \\
\text { pandemic }\end{array}$ & $\begin{array}{c}\text { During } \\
\text { Pandemic }\end{array}$ \\
\hline Yoga \& meditation & $5,4 \%$ & $4,3 \%$ \\
\hline Flexibility & $31,2 \%$ & $26,9 \%$ \\
\hline Ball games & $40,1 \%$ & $61,4 \%$ \\
\hline Strength & $59,9 \%$ & $53,4 \%$ \\
\hline Endurance & $55,4 \%$ & $60,1 \%$ \\
\hline
\end{tabular}

Based on the data on table 6 shown that the subjects have changed their pattern exercise because one of the reasons for this change in pattern is that the research subjects work around the home environment to increase income and help their parents. As much as 58.7\% from the all subjects work to increase income. The majority of students help work in agriculture (9\%), online sales (27.1\%), sports coaches (11\%), motorbikes (2.9\%), fitness instructors $(1.3 \%)$, physical education teachers $(0.9 \%)$ with others scattered in various types of work, such as pick-up driver, kite making, barista, paint shop, bus driver, shop guard, construction worker, security officer and batik stamp maker.

\section{DISCUSION}

Life in the COVID-19 pandemic condition requires humans to spend a long time every day at home. With this it results in reduced overall body movement. This static and stressful lifestyle can disrupt the body's immune system which can lead to various diseases, both non-infectious (degenerative) and infectious [13]. Sport is the best and cheapest option and effort to prevent yourself from getting sick, which people know and believe can increase immunity and increase the degree of health [14].

Based on the data that has been obtained, it is found that students experience changes in their physical activity caused by the COVID-19 pandemic. The changes shown were a decrease in the frequency of exercise. As much as $83.2 \%$ of students experienced a decrease in the frequency of training each week. Whereas the reduced frequency of exercise each week can affect the performance and ability of a person's physical condition [15].

In fact, it is well known that a person's low level of activity can have a negative impact on physical fitness [16]. The negative impact of low fitness levels is that the 
body becomes tired quickly, overweight, and is prone to symptoms of hypokinetic disease [17]. Therefore, fitness is very important so that they are able to do their daily tasks and activities without experiencing excessive fatigue [18].

This condition not only has a positive impact but also has a negative impact. The negative impact caused is a, or what is commonly called a sedentary lifestyle. Though sedentary lifestyle can be bad for one's health because of sedentary lifestyle is a risk factor for cardiovasculardisease $^{[19]}$. Not only causes cardiovascular disease, a number of studies say that a sedentary lifestyle can cause a person to suffer from obesity [20].

The reduced frequency of student training each week can affect learning achievement. A study has shown that sports activities are proven to develop learning abilities [21]. Sports activities can improve important functions, ability to concentrate, memory, and intellectual. Sports activities also stimulate the brain and cause the release of BDNF (Brain Derived Neurotrophic Factor) which affects thinking acuity, increased memory, focus, and concentration [22]. There are four very important points from the impact of sports activities in the process of increasing knowledge and thought processes, namely increasing the circulation of neurons so that a person has nutrition in his brain, stimulates the production of neurotransmitters that can improve mood and grows BDNF (Brain Derived Neurotrophic Factor) factors, creating cell processes, new brain cells called neurogenesis, and improved visual acuity [23].

The decrease in the frequency of training experienced by students is also due to the limited facilities and infrastructure that support the training process. As is well known, students usually use campus facilities to do exercises. However, with the COVID-19 pandemic conditions, many facilities and infrastructure are limited. During this pandemic many sports halls and gyms were closed in order to comply with government regulations. Whereas limited sports facilities can have an impact on a person's motivation to do sports [24]. By looking at the facts about the decrease in the frequency of students doing exercises, it can be concluded that there was a decrease in student motivation to do the exercises.

The decrease in student motivation in doing the exercises was also indicated by the fact that there was a decrease in the duration of the exercise. Based on the data, the subjects also applies to changes in the pattern of exercise duration time where $80.9 \%$ of the subjects experienced changes in exercise time. In fact, it is well known that a person will take benefit from exercise if they do sports activities with a duration of 150 minutes per week [25]. The decrease in exercise duration was caused by students feeling bored quickly when they only practiced at home. Even though students usually do routine exercises by participating in student activity units or participating in sports community movements on campus and they are carried out together with their colleagues. The environment can affect student interest in doing exercise activities. One of the factors that can increase students' interest in doing exercises is the existence of social interaction, if social interaction decreases, the student's interest in participating in an activity will decrease. The most influential source of social interaction in an activity is friends [26]. It is well known that during this pandemic, large scale social restrictions occurred. The public is encouraged to carry out physical distancing and social distancing in order to break the chain of transmission of the COVID-19 virus.

This pandemic condition also affects the intensity of student training. The results shown that the $82.3 \%$ subjects changed their exercise intensity patterns. These changes are in the form of a decrease in the intensity of exercise in students. Whereas someone who does physical activity properly must pay attention to the intensity of the exercise, the intensity of the exercise can be seen through the pulse [27]. Because whether someone is actually doing sports activities can be monitored through by the heart rate. Someone who does high intensity activities has a fast heart rate, someone who does sports activities using low intensity activities has a slower heart rate [28]. A person will get a training effect if they do sports activities using the intensity that is included in the training zone [27].

The decrease in the intensity of the exercises performed by students was caused by the absence of a sports coach or coach and accompanying lecturers. During the COVID-19 pandemic, they did it alone. With this, students experience decreased motivation in doing exercises. In order to increase one's motivation to actively carry out the exercises, it is necessary to have the role of a trainer to exert pressure on someone being trained [29].

Based on the data that has been obtained, it can be concluded that students have decreased and changed in the application of their physical activity during the COVID-19 pandemic. The decrease experienced by the students was in the form of a decrease in the frequency of exercise each week, a decrease in the duration of the exercise, and a decrease in the intensity of the exercise. In fact, as it is known, students should be required to increase and maintain immunity so they are not susceptible to viruses. One way to achieve this is by doing sports activities so that they can increase the body's immune system. The correct sports activity must pay attention to the frequency, intensity, type, and duration of exercise [30]. 
An example of the application of exercise using the FITT concept, for example, is by doing aerobics energy system exercises, the first is frequency that is the number of repetitions of activities within one week. This activity is generally carried out two to three times a week. The intensity of the exercise used is by measuring the maximum heart rate, we can find out the intensity of this activity. The intensity used in this activity is $60-80 \%$ of the maximum heart rate. The time it takes to do this activity is 20 to 60 minutes. Types of exercise, there are various kinds of aerobic activity, namely running, cycling, jogging, swimming, and walking [30].

Changes in the application of physical activity experienced by students are also due to economic aspects. The condition of the COVID-19 pandemic, some people have complained about the economic decline caused by the number of restricted activities. The results shown that the subjects have changed their pattern exercise because one of the reasons for this change in pattern is that the subjects work around the home environment to increase income and help their parents. As much as $58.7 \%$ from the all subjects work to increase income. The majority of students help work in agriculture $(9 \%)$, online sales $(27.1 \%)$, sports coaches (11\%), motorbikes $(2.9 \%)$, fitness instructors $(1.3 \%)$, physical education teachers $(0.9 \%)$ with others scattered in various types of work, such as pick-up driver, kite making, barista, paint shop, bus driver, shop guard, construction worker, security officer and batik stamp maker. Based on the data that has been obtained, it is not surprising that students experience changes and decreases in their application to physical activity.

Based on the data and facts that have been obtained, it is hoped that students will always maintain and increase their physical activity during this COVID-19 pandemic condition. To avoid contracting the COVID19 virus, the government has urged the public to always maintain cleanliness and lead a healthy lifestyle. A healthy lifestyle is by maintaining immunity by exercising based on FITT (Frequency, Intensity, Time, and Type) [30]. People are also advised to maintain nutritional intake and hydration. In addition, people are also advised to pay attention to the recovery of the body because a tired body will be susceptible to various viruses and diseases [30].

\section{CONCLUSION}

Based on the data that has been obtained, It can be concluded that during the pandemic, the majority of students changes their exercise patterns during the COVID-19 pandemic. The decrease experienced by the students was in the form of a decrease in the frequency of exercise each week, a decrease in the duration of the exercise, and a decrease in the intensity of the exercise.
Students must have to always maintain cleanliness and lead a healthy lifestyle. A healthy lifestyle is by maintaining immunity by exercising based on Frequency, Intensity, Time, and Type. Sport is the best and cheapest option and effort to prevent yourself from getting sick, which people know and believe can increase immunity and increase the degree of health. Students will take the benefit from exercise if they do sports activities with a duration of 150 minutes per week. Furthermore It is suggested to conduct further research on different research subjects with a larger number of subjects.

\section{ACKNOWLEDGMENT}

The authors would like to thank the Sports Coaching Education Study Program, Faculty of Sport Science, Universitas Negeri Surabaya for providing funding for this research.

\section{REFERENCES}

[1] WHO. Coronavirus. [Online]. Available: https://www.who.int/healthtopics/coronavirus\#tab=tab_1. Accessed April 23, 2020.

[2] NIAID. COVID-19, MERS \& SARS | NIH: National Institute of Allergy and Infectious Diseases. [Online]. Available: https://www.niaid.nih.gov/diseasesconditions/COVID-19. Published 2020. [Accessed April 27, 2020].

[3] N. Zhu, D. Zhang, W. Wang, et al., "A novel coronavirus from patients with pneumonia in China, 2019," N Engl J Med, vol. 382, no. 8, pp. 727-733, 2020. Doi: 10.1056/NEJMoa2001017.

[4] W. Guan, Z. Ni, Y. Hu, et al., "Clinical characteristics of 2019 novel coronavirus infection in China," $N$ Engl J Med., 2020. Doi:10.1101/2020.02.06.20020974

[5] Suara Surabaya, "Mulai Hari Ini, Seluruh Kegiatan Perkuliahan di Unesa Dibuat Daring - Suara Surabaya." [Online]. Available: https://www.suarasurabaya.net/kelanakota/2020/m ulai-hari-ini-seluruh-kegiatan-perkuliahan-diunesa-dibuat-daring/. [Accessed June 28, 2020].

[6] CNN Indonesia, "60 Persen Mahasiswa Pulang Kampung, Kuliah Online Kala Corona.” [Online]. Available:

https://www.cnnindonesia.com/teknologi/2020040 9161641-185-492172/60-persen-mahasiswapulang-kampung-kuliah-online-kala-corona. [Accessed June 28, 2020]. 
[7] D. Jiménez-Pavón, A. Carbonell-Baeza, and C. J. Lavie, "Physical exercise as therapy to fight against the mental and physical consequences of COVID19 quarantine: Special focus in older people," Prog Cardiovasc Dis., 2020. Doi:10.1016/j.pcad.2020.03.009

[8] Health Gov., "Scientific Report." [Online]. Available: https://health.gov/our-work/physicalactivity/current-guidelines/scientific-report. [Accessed June 28, 2020].

[9] D. J. Korczak, S. Madigan, and M. Colasanto M, "Children's physical activity and depression: A meta-analysis," Pediatrics, vol. 139, no. 4, 2017. Doi:10.1542/peds.2016-2266

[10] E. A. Haapala, J. Väistö, N. Lintu, et al., "Physical activity and sedentary time in relation to academic achievement in children," J Sci Med Sport, vol. 20, no. 6, pp. 583-589, 2017. Doi:10.1016/j.jsams.2016.11.003

[11] R. Guthold, G. A. Stevens, L. M. Riley, and F. C. Bull, "Global trends in insufficient physical activity among adolescents: a pooled analysis of 298 population-based surveys with 1.6 million participants," Lancet Child Adolesc Heal., vol. 4, no. 1, pp. 23-35, 2020. Doi:10.1016/S23524642(19)30323-2.

[12] F. Halabchi, Z. Ahmadinejad, and M. SelkGhaffari, "COVID-19 Epidemic: Exercise or Not to Exercise; that is the Question!" Asian J Sports Med., vol. 11, no. 1, 2020. Doi: 10.5812 /asjsm. 102630

[13] N. Owen, P. B. Sparling, G. N. Healy, D. W. Dunstan, and C. E. Matthews, "Sedentary behavior: Emerging evidence for a new health risk," Mayo Clin Proc., vol. 85, no. 12, pp. 1138-1141, 2010. doi:10.4065/mcp.2010.0444.

[14] A. D. Arad, F. J. Dimenna, N. Thomas, J. TamisHolland, R. Weil, A. Geliebter, \& J. B. Albu, "High-intensity interval training without weight loss improves exercise but not basal or insulininduced metabolism in overweight/obese African American," Vol. 119. 2015.

[15] M. N. Blue, A. E. Smith-Ryan, E. T. Trexler, \& K. R. Hirsch, "The effects of high intensity interval training on muscle size and quality in overweight and obese adults," Journal of Science and Medicine in Sport, Vol. 21, No. 2, 2017.

[16] J. E. Blümel, P. Chedraui, S. Aedo, J. Fica, E. Mezones-Holguín, G. Barón, F. Laribezcoa, "Obesity and its relation to depressive symptoms and sedentary," Maturitas, vol. 80, no. 1, 2015.
[17] Y. Niu, D. Zhou, \& Z. Ma, "Effect of aerobic exercises on students. Science \& Sports," vol. 33, no. 2, 2018.

[18] C. M. Palar, D. Wongkar, \& S. H. Ticoalu, "Manfaat latihan olahraga aerobik terhadap kebugaran fisik manusia," vol. 3, 2015.

[19] G. Lessiani, F. Santilli, A. Boccatonda, P. Iodice, R. Liani, R. Tripaldi, and G. Davì, "Arterial stiffness and sedentary lifestyle: Role of oxidative stress," no.76, 2016.

[20] C. L. Ogden, M. D. Carroll, H. G. Lawman, C. D. Fryar, D. Kruszon-Moran, B. K. Kit, et al., "Trends in Obesity Prevalence Among Children and Adolescents in The United States 1988-1994 through 2013-2014," 2016.

[21] C. M. Nascimento, J. R. Pereira, L. Pires de Andrade, M. Garuffi, C. Ayan, D. S. Kerr, et al., "Physical exercise improves peripheral BDNF levels and cognitive functions in mild cognitive impairment elderly with different bdnf Val66Met genotypes," J Alzheimers, 2015. DOI: 10.3233/JAD-140576

[22] K. Sadeghi, S. M. Ahmadi, M. Rezaei, J. Miri J, A. Abdi, and K. A. Jamshidi, "A comparative study of the efficacy of cognitive group therapy and aerobic exercise in the treatment of depression among the students," Global Journal of Health Science, 2016.

[23] A. Dinoff, N. Hermann, W. Swardfager, C. S. Liu, C. Sherman, S. Chan, and K. L. Lanctot, "The effect of exercise training on resting concentrations of peripheral brain-derived neurotrophic factor (BDNF): A meta-analysis," 2016.

[24] D. Sujana, Dampak simultan manajemen sarana prasarana dan peran kepemimpinan terhadap pembangunan olahraga. 2018.

[25] F. M. Grace, P. Hebert, A. D. Elliott, J. Richards, A. Beaumont, and N. F. Schulthorpe, "High intensity interval training (HIIT) improves resting blood pressure, metabolic (MET) capacity and heart rate reserve without compromising resting myocardial function in sedentary aging men," 2017.

[26] L. Ortega, I. Montalvo, R. Monseny, E. Viella, J. Labad, "Perceived stress mediates the reliatinship between social adaptation and quality of life in individuals at ultra high risk of psychosis," 2018.

[27] K. Ashadi, "Implementasi fisiologi olahraga pada olahraga prestasi," Prosiding: Pertemuan ilmiah ilmu keolahragaan nasional Univeritas Negeri Malang, 2014.

[28] K. Ashadi, D. N. Mirza, \& G. Siantoro, "Hydration status in adolescent runners: pre and post training," vol. 296, 2018. 
[29] Muslima, T.F., Himam, F. Peran pelatih dalam pembinaan prestasi atlet pada organisasi taekwondo professional. 2016.

[30] Andriana, L.M., Ashadi, K. 'Perbandingan dua jenis aktivitas olahraga di pagi dan malam hari terhadap kualitas tidur', Jurnal Penelitian Pembelajaran, (5) 1, 98-112. 2019. 